\title{
The Relationship between Medical and Wellness Therapies in the Treatment of Chronic Musculoskeletal Diseases
}

\author{
Szilvia Boros* and Mike Wallace \\ Department of Tourism and Catering, University College of Szolnok, Hungary
}

Received: May 27, 2014; Accepted: July 04 , 2014; Published: July 09, 2014

*Corresponding author: Szilvia Boros, Department of Tourism and Catering, University College of Szolnok, Hungary, Email: szilviaboros@gmail.com

According to the latest scientific estimation, approximately 100 million citizens in the European Union are suffering from chronic musculoskeletal pain [1]. For example in Hungary, 47.9 $\%$ of men over 65 years and $48.9 \%$ of women over 62 years suffer from back pain [2].

Behind non-specific musculoskeletal complaints a number of risk factors can be detected [3]. such as genetic predisposition, obesity, extreme height, spinal deformities, pregnancy, psychological stress, stress arising from family conflicts, anxiety, depression, ageing, work-related stress (insecure working conditions, limited personal decision-making opportunities, minimum workplace autonomy, lack of job satisfaction, monotony, intense pace of work, unrealistic expectations, etc ).

The question can be raised, which type of non-invasive preventative methods can alleviate the musculoskeletal complaints? Looking at various wellness treatments which ones in particular can effectively contribute to musculoskeletal pain relief?

Balneotherapy involves a multifaceted therapeutic use of natural resources, medicinal water in particular which is mainly connected to the thermal effects of hot spring mineral water. However Balneotherapy can also include mud packing, mineral drinking water, climate and even cave therapies [4]. A Balneotherapy 'cure' or stay is generally carried out in a course of approximately 10 - 24 treatments. In general, the duration of the treatments last between 20 to 40 minutes. This complex treatment is a very effective for musculoskeletal disorders [5]. Indications include; low back pain, rheumatoid arthritis, degenerative osteoarthritis, arthropathia sporiatica and fibromyalgia. This treatment is not suitable for acute inflammation, fever, angina pectoris and psychiatric disorders, heart failure, and acute skin infection.

The bath types used in Balneotherapy include the carbon dioxide bath, which involves surface vasodilatation. Its effects help reduce peripheral vascular resistance, as a result the skin is saturated with oxygen and the condition of the connective tissues and muscles improve. Breathing also deepens, which improves oxygen uptake. It is not only suitable for the treatment of musculoskeletal diseases but also for cardio-vascular diseases, type- 2 diabetes mellitus and general health.
Hungarian thermal waters are rich in sulphur, which can be separated into three forms: a sulfide, sulfate and amorphous sulfur. Part of the sulfur is absorbed through the skin, the rest is absorbed into the body through inhalation. It has the ability not just to penetrate through the skin, but also into other tissues, for example the cartilage where it is able to build itself into the tissue. This is invaluable for the treatment of joint deformities and its effects notably alleviate pain and stiffness.

In radon containing water, radioactive rays are emitted and absorbed into the tissues via inhalation and the skin. It causes also vasodilatation, and as a result hypotension occurs combined with a considerable reduction in pain levels.

Iodine-bromine waters have very effective anti-inflammatory properties. They facilitate the elimination of edema, as well as stimulate ovarian function, positively help balance blood glucose and reduce uric acid levels. They successfully help regenerate musculoskeletal disorders and are an effective treatment for extreme physical exertion and can support post-operative rehabilitation [6].

Under the umbrella of Balneotherapy are also 'mofettes', which literally mean "stinking fumes." Mofette are found in places of volcanic activity where natural carbon dioxide gas is emitted through the earth's surface. In Hungary, they are only found in Mátraderecske, however they are widespread in Transylvania, Slovakia and in Italy. There are two types, wet and dry and these two types of mofettes can be distinguished from each other. The wet mofette is prevalent in carbonated mineral or acidic water and the dry in the form of carbon dioxide gas. These have a powerful vasodilator effect on hypertension and are used for the treatment of atherosclerosis, osteoporosis and degenerative joint diseases.

The hungarian mud therapy is recognized internationally as a unique and highly effective method of treatment [7]. It is a therapy that needs to be prescribed by a doctor as a heat treatment for chronic disease conditions that affect bodily movement. The medicinal mud is referred to as 'healing earth', as it contains many valuable minerals, trace elements and organic constituents of plant and animal remains. Besides the chemical properties the heat plays an important role as it retains heat four times better than water. Hungarian peat is located in four 
sites: Hévíz, Tiszasüly , Mako, Hajduszoboszlo . Two hungarian medical doctors, béla lengyel, and later vilmos hankó noticed the high iron and sulfate content of the tiszasülyi mud and in 1898 he described its effectiveness in scientific publications. As a result, some 70 years later, the ministry of health declared it medicinal mud. The mud is used for treating not only of arthrosis, gout arthritis, chronic tendonitis, fibromyalgia and sports injuries, but is also prescribed for post-operative rehabilitation, gynecological disorders and chronic inflammation. The duration of treatment is 20 minutes in which at a temperature of $40-42 \mathrm{c}$ the mud is applied onto the painful part of the body and is carefully wrapped in foil, a sheet and blanket and then allowed to cool.

\section{Wellness treatment of musculoskeletal disorders}

If we assume that the majority of musculoskeletal disorders occur due to lifestyle factors, it seems almost self-evident that many wellness products can help prevent the development of musculoskeletal symptoms by alleviating the root causes. Stress management is a prominent therapy followed by other therapies such as relaxing massages, aromatherapy, body treatments, saunas, pools, flotation, jacuzzis and a wide range of sport activities, including yoga, tai - chi, chi kong. Mind-body procedures such as meditation, autogenic training, progressive muscle relaxation are also effective.

A range of wellness spa treatments are able to directly have a positive impact on musculoskeletal complaints. Aqua gym and spa therapy together result in a significant short -term relief of musculoskeletal complaints [8]. Kim et al. [9] obtained evidence from tests that the marjoram, lavender, rosemary and peppermint essential oils 2:1:2:1:1 mixture was effective in reducing pain and depressive symptoms. Massage could also effectively reduce stiffness of shoulder muscles and increased range of motion [10]. Four-hundred people participated on the research of measuring the effects of relaxation and therapeutic massage in chronic back pain. The results showed that relaxation and massage together reduced chronic back pain for at least six months [11]. In summary, wellness supplies together with balneotherapy may play important role in the treatment of several chronic musculoskeletal disorders.

\section{References}

1. Veale DJ, Woolf AD, Carr AJ. Chronic musculoskeletal pain and arthritis: Impact, attitudes and perceptions. Ir Med J. 2008; 101 (7): 208-210.

2. KSH. Október elseje az idősek világnapja 2012 - a tevékeny idősödés és a nemzedékek közötti szolidaritás európai éve; Statisztikai tükör. 2012; VI. évf. 75sz.

3. Bevan S, McGee R, Quadrello T. Fit for work? Munkaképes?, Mozgásszervi megbetegedések és a magyar munkaerőpiac. The Work Foundation. 2010;

4. Csermely M. Gyógyfürdők és gyógyvizek. Budapest:White Golden Book Kft.; 2002

5. Zauner R. A hátfájdalmak természetes gyógymódja, Medicina, Bp. 1990.

6. Bálint-Bender . A fizioterápia elmélete és gyakorlata, Budapest: Springer Kiadó; 1995.

7. Kósa L. Fürdőélet a Monarchiában, Holnap Kiadó, Bp. 1999.

8. Kamioka H, Tsutani K, Okuizumi H, Mutoh Y, Ohta M, Handa S, et al. Effectiveness of aquatic exercise and balneotherapy: a summary of systematic reviews based on randomized controlled trials of water immersion therapies J Epidemiol. 2010; 20(1):2-12.

9. Kim MJ, Nam ES, Paik SI. The effects of aromatherapy on pain, depression, and life satisfaction of arthritis patients. Taehan Kanho Hakhoe Chi. 2005; 35(1):186-94.

10. Yang JL, Chen SY, Hsieh CL, Lin JJ. Effects and predictors of shoulder muscle massage for patients with posterior shoulder tightness. BMC Musculoskeletal Disorders. 2012;13:46. doi:10.1186/1471-2474-1346.

11. Cherkin DC, Sherman KJ, Kahn J, Wellman R, Cook AJ, Johnson E, et al. A comparison of the effects of 2 types of massage and usual care on chronic low back pain: a randomized, controlled trial. Ann Intern Med. 2011; 155(1):1-9. doi: 10.7326/0003-4819-155-1-20110705000002. 